\title{
Perceived qualities of a 'good' chairman: a challenge for corporate governance in South Africa
}

\author{
Mike Bendixen \& Adèle Thomas* \\ Graduate School of Business Administration. Lniversity of the Witwatersrand. P.O. Box 98 . Wits 2050 South Africa \\ thomasa â zeus mgmt wits ac za \\ adelet ä megaweb.co.za \\ mikeb aicamatico za
}

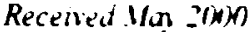

\begin{abstract}
Corporate governance is increasingly being viewed as essential to sound business practice The recommendations of the Cadbury Committee in the United Kingdom with respect to the role of a chairman are similar to those later formulated in the King Report on Corporate Governance in South Africa In the present study the perceived qualities of gowd charmen

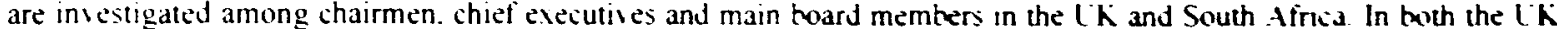
and in South Africa the same robust methodolog! was used. enabling an inter-countr comparison of resuits. The l h studs comprised 60 in-depth interviews followed by a mailing of tho quesionnaires to which $11^{-}$man-ruard memters responded the South African study comprised is in-depth intervews followed by a mailing of $2+18$ questromalres to which 274 main-board members responded. In both cases. in the analvsis. four-fack and four-cluster solutions emerged vot surprisingly. the results for the two countries are quite different from each other and difierent profiles of preferred chairmen "were lound. In the case of the $\mathrm{CK}$. the most preferred protile supports the execution of roles recommended for gound gorernance while in South Africa. the least preferred profile appears to the the most appropriate
\end{abstract}

* Author to whom correspondence should be addressed.

\section{Introduction}

In a quest to safeguard the interests of stakeholders. in general, and shareholders. in particular, the issue of corporate governance has increasingly emerged as a prominent issue in business. This awareness stimulated the formulation. in the UK, of the Cadbury (1992) and Greenbury (1995) Reports and the subsequent review of adherence to recommended codes of practice by the Hampel Report (1998). Conyon (1994) notes that the overall picture that emerges in UK companies is one of radical change in governance innovation between 1988 and 1993 and Conyon \& Mallin (1997) later report a high level of compliance with the recommendations furnished in the Cadbur Report (1992). In a similar vein. the King Report (1994) and related codes of practice were formulated in South Africa. Subsequent research (Ronan. 1996; Rossouw, 1997) has endeavoured to highlight some specific issues of corporate governance in relation to the particular South African environment, such as employee participation, affirmative action programmes and work ethic.

The Institute of Directors (1995) proposes four dilemmas that directors of boards face:

- Being simultaneously entrepreneurial whilst exercising prudent control:

- Being knowledgeable about operations whilst retaining an objective. long-term view:

- Being sensitive to short-term pressures yet being informed about external trends; and

- Being focused on commercial needs whilst acting responsibly tow ards stakeholders.

The role and the qualities of the chairman will determine the success with which the board deals with these dilemmas

\section{Literature review}

An international perspective on corporate governance

The importance of corporate gotemance. internationally. in both the private business sector and in state-owned enterprises. is noted in the guidelines documented bs the Commonwealth Association for Corporate Govemance (CACG) (1999). In this report. it is stated that

the fact is that good corporate governance practices are now becoming a necessit for even countr and business enterprise. and are no longer restricted to the activities of public-listed corporations in adranced industrial economies ' (CACG. 1999: 1).

In addition to the legalistic connotations of the Cadbur (1992) and King (1994) Reports. a subst untive amount of academic research on corporate governance. in general. has been undertaken in the past two decades (Fidler. 1981: Herman. 1981: Dalton \& Kesner. 1987: Kosnik. 1987: Stew art. 1991: Demb \& Neubauer. 1992: Coulson-Thomas. 1993: Useem. 1993: Charkham. 1994: Blair. 1995: Boyd. 1995: Daily \& Dalton. 1995: Dulewicz. Macmillan \& Herber. 1995: Jackson \& Carter. 1995: Pettigrew \& McNultr. 1995: Starkes. 1995: Westphal \& Zajac. 1995: Shleifer \& Vishnev. 1997: Clarke. 1998: Conger. Finegold \& Lawler. 1998: Vinten. 1998).

Rechner \& Dalton (1991) and Mallette \& Fowler (1992) have demonstrated the impact on board performance of board leadership structure and Clarke (1998:119) notes that in the longer term 'only' sound leadership and governance can aroid unnecessary decline and collapse (of a company)'. Similarly. Conger et al. state that 
'while no one can yet show a direct link between a board's effectiveness and its company's profits, few would be likely to disagree that improved board performance translates into better corporate governance' (1998: 138).

In stressing the importance of corporate governance, Herman (1981), Matter \& Ball (1985) and Waldo (1985) highlight the role of the board in counselling, evaluating and controlling company management. The CACG Report (1999) notes that corporate governance is essentially about leadership for efficiency and for probity, and that such leadership should be undertaken responsibly in a manner that is transparent and accountable.

Besides ensuring organisational effectiveness and efficiency, Garratt (1996) and the CACG Report (1999) note that performance and conformance are key roles of the board. Performance relates to a focus on the external environments while conformance is 'the internal focus of the board on its performance to pre-set of accountability to its stakeholders; and to its business performance through its people' (Garratt, 1996: 10).

\section{Shareholder versus stakeholder focus in corporate gov- ernance}

Starkey (1995) notes how research into corporate governance has been dominated, in the past, by legal, economic and financial issues and Daily \& Dalton (1995) maintain that, historically, corporate performance indicators have concerned accounting and shareholder returns only. Increasingly, however, attention is being focused on the issue of stewardship, or as earlier stated by Mintzberg (1984) and later by Blair (1995), the questioning of who should control the company, how it should be controlled and what goals it should be pursuing. The issue of such control, Pettigrew \& McNulty (1995) believe, is fundamentally linked to an awareness of who should be represented in decision-making at board level. Accordingly, the accountability of the board to shareholders only has been questioned (Blair, 1995; Clarke, 1998) in favour of the extension of such inclusion to all significant stakeholders. The focus of accountability to shareholders alone cannot, according to Clarke,

'persist much longer in a commercial world where every practicing manager knows survival depends on winning and pleasing customers; on having a versatile, willing and capable workforce; on forging partnerships with suppliers; and on maintaining credibility in the wider community' (1998: 121).

Rather, governance should be broadened to include multiple interest (Starkey, 1995), dynamic network structures (Miles \& Snow, 1986) and strategic alliances (Jarillo, 1998), including relationships with customers and employees (CoulsonThomas, 1994), the general public, politicians, institutional fund managers, listings directors, directors' and officers' liability insurers and directors themselves (Garratt, 1998). This point is reinforced by the CACG Report in which it is stated that

'good corporate governance requires that the board must govern the corporation with integrity and enterprise in a manner which entrenches and enhances the licence it has to operate. This licence ... embraces the corporation's interaction with its shareholders and other stakeholders such as the communities in which it operates, bankers and other suppliers of finances and credit, customers, the media, public opinion-makers and pressure groups' (1999: 6).

In strengthening the expanded focus of corporate governance to stakeholders, Pettigrew \& McNulty note:

'There is now ample evidence from organizations of many different kinds, in many societies, that the power and influence of senior decision holders is contained by the countervailing influence of others inside and outside their own organizations, as well as by rules, traditions, and other institutional arrangements' (1995: 848).

In summary, in the CACG Report it is noted that 'while the board is accountable to the owners of the corporation (shareholders) for achieving the corporate objectives, its conduct in regard to factors such as business ethics and the environment for example may have an impact on legitimate societal interests (stakeholders) and thereby influence the reputation and long-term interests of the business enterprise' (1999: 6)

This Report articulates 15 principles to which the members of boards should comply to ensure effective corporate governance.

\section{Structure of the board}

Garratt (1996) identifies four board structures that are typically found around the world.

\section{Non-executive board}

Such a board comprises notionally independent nonexecutive directors who decide policy and strategy that is then delegated to the chief executive for implementation. The chief executive wields enormous power in controlling the information flowing to and from the board. This has the potential for corruption. Such board structures are common the USA, New Zealand and among public and semi-public service boards.

\section{Executive board}

The structure of this board allows for the dominance of the chief executive who may often also adopt the role of the chairman. This structure is characterised by a lack of diversity and a cloning of membership is common. The influence of independent external directors is lacking. This is the most common board structure and is often found in owner-director and family business.

\section{Two-tier board}

This comprises an upper (supervisory) board that deals with strategic issues and lower (operational) board that represents the different interest groups of the organisation. The separateness of the boards can prove problematic and allow political issues to dominate. Both boards can lose sight of working towards a common goal. This structure is commonly found in Germany, France and the Netherlands and has been proposed as a model for board in the European Union. 


\section{Unitan board}

This structure represents the traditional Angla-Saxon model. This board is led by the chief executive and the functional executive directors who are responsible for the operations of the business. Independent non-executive directors formulate policy. ensure accountability and provide debate and constructive criticism of the chief executive's performance. Such independent directors, led by the chairman. ensure both conformance and performance of the board in the interests of shareholders and other stakeholders.

\section{Competencies of directors}

Coulson-Thomas (1994) identifies the following diverse attributes and qualities of directors: integrity: wisdom. authorit. judgement. leadership. courage. independence, a positive cutlook, tact. diplomacy, awareness of business environment. a sense of accountability to stakeholders, vision. strategic perspective, business acumen. knowledge of relevant legal and financial issues, an understanding of board functions. management skills, contextual experience and ethical awareness He further adds:

'A competent director needs to be a team player whose attributes complement the qualities of the existing members of the boardroom team ' (Coulson-Thomas. 1994: 35).

Garratt (1996) identifies seven development needs for directors:

- Independence of thought and action;

- Capacity to be responsible yet detached;

- Ability to take an holistic view of issues;

- A portfolio of thinking styles to cope with the diversity of board issues:

- Ability to reflect and debate issues;

- Ability to link policy and strategic thinking with implementation;

- Ability to time-budget for direction-giving as distinct from managing.

Both Coulson-Thomas (1994) and Garratt (1996) concur that directors appear to receive little formal training for their boardroom roles.

\section{Cadbury and King Reports}

The chairman of the board has the major responsibilit for ensuring the competence of individual board members and that the board as a whole is effective (Coulson-Thomas. 1994). Coulson-Thomas (1994) further notes how. in this role. the chairman has a direct influence on attitudes and behaviours that impact on corporate performance.

The role of a chairman, as outlined by the Cadbury (1992) and King (1994) Reports, include:

- Ensuring that the board is balanced in terms of company strategy and structure;

- Ensuring the implementation of strategy by executive management:

- Ensuring financial and operational systems of control:

- Ensuring the ethical operation of the company:

- Selecting the chief executive, advising on the appointment of senior executives. succession planning and other company benefits:
- Taking an objective view of the day-to-da! nunning of the business:

- Inferming board members to ensure quality- decision-making:

- Ensuring the full participation by executive and non-executive directors in corporate governance

It is interesting to note that the Cadbun and King Reports focus upon the roles that a chairman should perform. rather than the qualities of the person.

In thoth the Cadburn (1992) and King (1094) Reports and in related research. the role of the chaiman and especially the delineation of roles betu een the chairman and the chief executive. has emerged as a kel issue in governance ( Heidenbaum. 1986: Patton \& Baker. 1987: Lorsch. 1989. Morck. Shleifer \& Vishny. 1989: Dabrzynski. 1991: Mallette \& Fouler. 1992). Clarke (1998) notes hou a recent LK stud. reveals that the proportion of companies with combined chairman and chief executive has fallen from $17.8^{\circ}$, in 1993 to $11.2 \%$ in 1996. Argenti (1976) identifies that a combined chairman and chief executive is one of the symptoms of corporate collapse. Concem has been expressed in South Africa with regard to the tendency for companies listing abroad to appoint the same person to position of chairman and chief executive (Southey, 1999)

\section{Aims of the study}

The aims of the present study were. in the light of the Cadbury (1992) and King (1994) Reports, to:

- Identify the perceived qualities of a 'gond' chairman in both the UK and in South Africa:

- Identifi. the underlying constructs that differentiate such perceptions:

- Identify differing categories of perceived 'good' chairman:

- Contrast the UK and South African findings: and

- Highlight the implications of the qualities of chairmen for corporate governance in South Africa.

\section{Methodology}

This research was originally conceived by Michael Knight of the Corporate Consulting Group in London. The first author conducted the analysis of the data and was involved in the interpretation of the results. The South African study was conducted under the auspices of Woodbum Mann, the Wits Business School and the Institute of Directors in Johannesburg. Both authors were involved in all aspects of the South African study:

A wo-phased research approach was adopted in both the UK and in South Africa. In the first phase. a reperton grid technique (Kelly, 1955: Fransella \& Bannister, 1977) was used whereby interviewees were required to describe the contrasting qualities of 'good' chairmen. The advantage of using the repertory grid technique is that constructs can be phrased using the 'language' of the respondents. The emerging constructs formed the basis of a self-completion questionnaire where respondents were asked to rate the items using a sixpoint bi-polar Stapel scale. Multivariate techniques were used to analyse the data. Correspondence analysis was used to rescale the data from ordinal to interval values (Bendixen \& Sandler. 1995). The rescaled data was subjected to principal 
Table 1 Instrument design and sample composition

\begin{tabular}{ll}
\hline United Kingdom study & South African study \\
\hline $\begin{array}{l}60 \text { In-depth interviews among chairmen and chief executives of listed } \\
\text { companies }\end{array}$ & 15 In-depth interviews among chairmen and chief executives of companies \\
36 contrasting statements emerged for use in the questionnaire & 41 contrasting statements emerged for use in the questionnaire \\
400 self-completion questionnaires mailed to main board members of large & $\begin{array}{l}2418 \text { self-completion questionnaires mailed to main board members of leading } \\
\text { South African companies }\end{array}$ \\
$\begin{array}{ll}\text { UK listed companies } & 274 \text { useable responses received (11\%) }\end{array}$ \\
\hline 17 useable responses received (29\%)
\end{tabular}

component factor analysis to extract the underlying differentiating themes that describe a 'good' chairman. The factor scores were then subjected to k-means cluster analysis in order to categorise respondents into groups having similar perceptions of what constitutes a 'good' chairman.

The research process and sampling are summarised in Table 1 .

In the UK study (conducted in 1996), 60 in-depth interviews formed the basis of the constructs that were used in the compilation of the self-completion questionnaire. These constructs were supplemented by a further 15 in-depth interviews in South Africa (conducted in 1998) to establish relevance and to capture differences germane to that environment.

As is evident from Table 1, a $29 \%$ response rate was achieved in the UK study, mainly as a result of significant follow up by the researchers. The South African response rate, while more modest, was unsolicited and well within acceptable norms (Leedy, 1997).

\section{Limitations of the study}

It should be noted that in the South African study, English was the language medium used which could have been the second or third language of some of the respondents despite it being the dominant language of business in the country. Accordingly, the possibility of misunderstanding of terminology could be present, although, given the nature of the sample (chairmen, chief executives and main board members), it is unlikely that this constituted a major limitation.

As with all postal surveys, there may be some unmeasureable bias in the responses in that certain respondents have a greater predisposition to respond than others.

The responses as to what constitutes a 'good' chairman were elicited from main board members only and primarily from such members of large corporations. The study did not elicit responses from broader stakeholder groupings nor from board members of smaller companies. Accordingly, the results of the present study reflect opinions only of the identi- fied sample and, while such board members, arguably, constitute a major component of 'business UK' and 'business South Africa', different results could have emerged had the study been broader in focus.

Due to the confidential nature of the study, respondents were not requested to identify their race or gender. Awareness of such details would have enriched the analysis of the findings.

The findings of the study have not been linked to the roles and embedded psychological and behavioural attributes of ideal chairmen. Ideally, a study that links qualities, roles, attitudes and behaviours of chairmen would provide a more comprehensive picture of what constitutes a 'good' chairman.

From the literature review, not much research is apparent regarding the qualities of chairmen. Available literature, mainly in the form of reports on corporate governance, focus primarily on the roles of chairmen. Accordingly, the findings of the present study could not be contrasted with findings emanating from previous research.

\section{Results}

\section{Results of the factor analysis}

In both the UK and the South African studies, four-factor solutions yielded the most meaningful results. The four factors, with contrasting poles in the UK study are summarised in Table 2.

The four factors, with contrasting poles, in the South African study are summarised in Table 3 .

\section{Contrasting the factors}

The UK 'directive' and South African 'authoritarian' poles are very similar, with the latter being somewhat more charismatic. The UK 'visionary' and the South African 'empowering' poles are also very similar, with the latter being more team-oriented. The UK and the South African 'passionate' poles are similar, with the latter being somewhat

Table 2 Contrasting poles of the UK factors

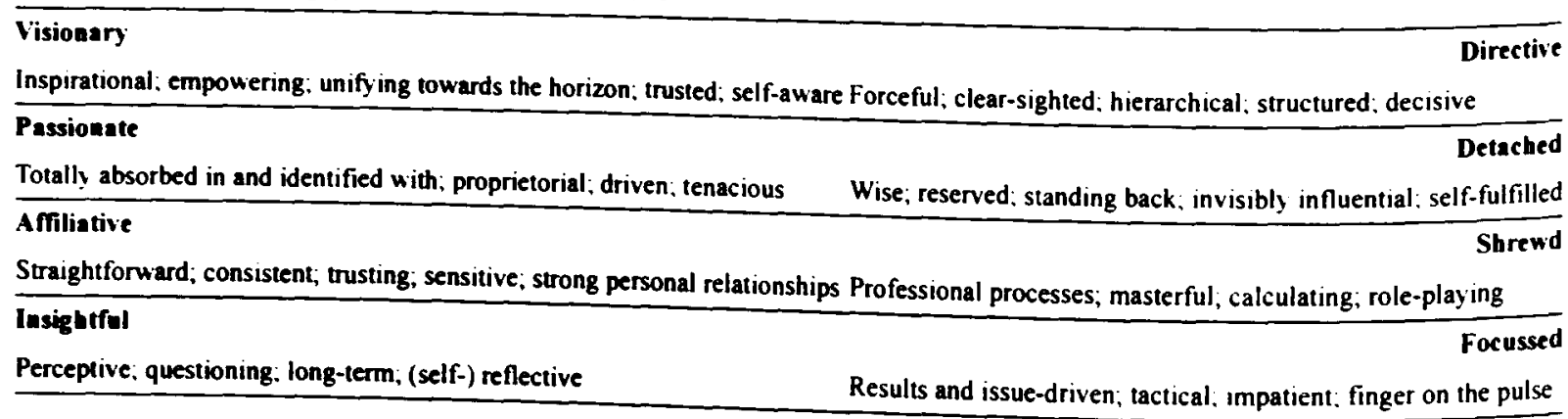


Table 3 Contrasting poles of the South African factors

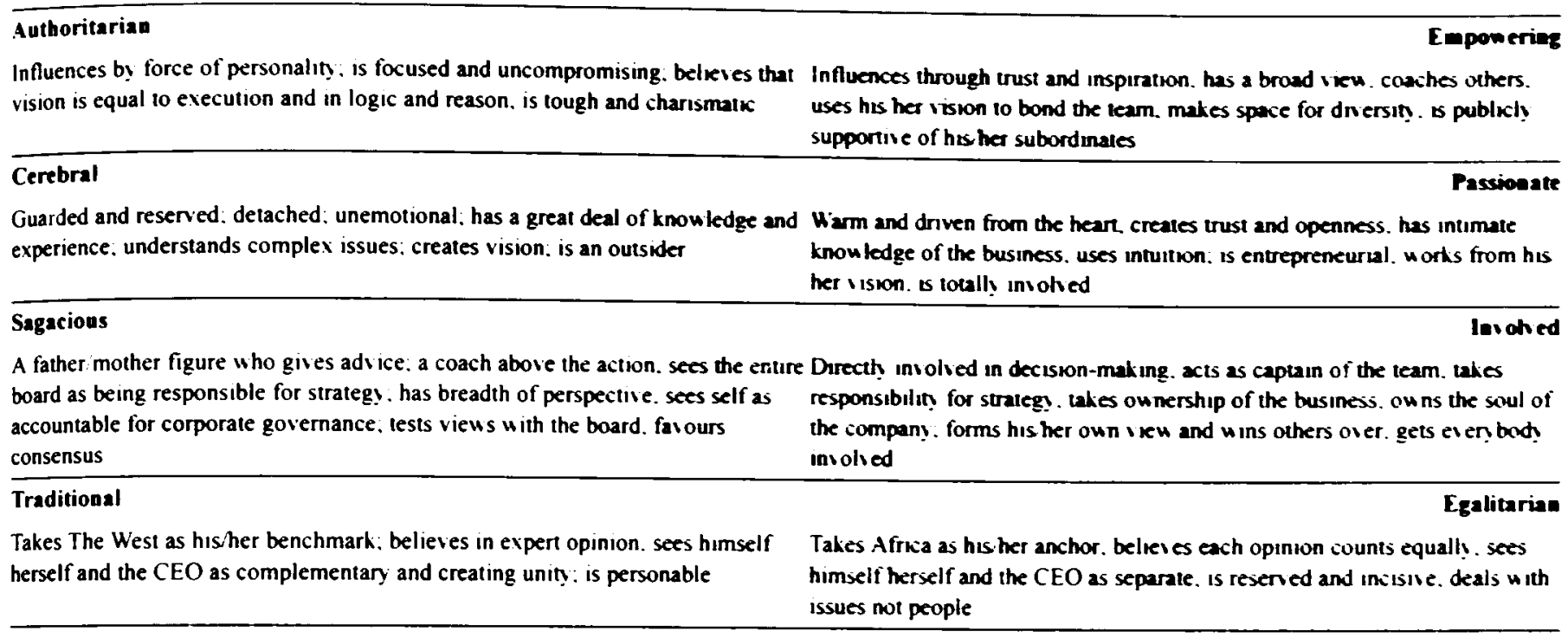

more intuitive. The UK 'detached' and the South African 'cerebral' poles evidence some similarity, with the latter displaying greater elements of knowledge.

The remaining two factors, namely 'affiliative' and 'insightful' (UK) and 'sagacious' and 'traditional' (South Africa) appear not to display much similarity.

\section{Results of the cluster analysis}

In both the UK and the South African studies four-cluster solutions yielded the most consistent results.

In the UK study, four archetype preferred profiles of chairmen were identified.

\section{The facilitator ( $32 \%$ of respondents)}

The facilitator works with and through a chief executive and evidences a 'hands-off' managerial style, coupled with open and warm personal relationships that extend to board members. Objectivity, experience, vision. sensitivity and purposeful style are the hallmarks of this profile that captures the elements of being both an outsider and an insider. This chairman regards his/her role as one of facilitating unity and commitment and avoids competition with hisher chief executive.

\section{The thinker ( $25 \%$ of respondents)}

While the thinker is visionary, he/she is, at the same time, detached. While this chairman works through a chief executive, he/she subtly and discretely uses his her own power and private agendas. This chairman is challenging. professional, intellectual and analytical, and is a skillful role-player who understands issues relating to business and people. In this scenario, the chief executive is the visible leader in the background, and major issues or decisions are likely to be those of the chairman.

\section{The driver ( $23 \%$ of respondents)}

The driver is both a directive and passionate leader. evidencing dominance in the board through force of personality. This chairman is unquestionably the boss and any chief executive will occupy the number two position. His her emphasis is upon issues of implementation and there is less regard for analysis. issues of process or communication of vision. He she requires total loyalty and commitment to him her and to the company and regards the two entities as one.

\section{The integrator ( $20 \%$ of respondents)}

The integrator is visionary, passionate. open. trusting. empathetic and empowering. and through intellectual rigour and developed communication and relationship skills, wins both hearts and minds. This chairman evidences a combination of strong strategic and analytical skills and is deeply immersed in the business. This chairman can be characterised as someone who is strategically hands-on', yet operationally 'handsoff. and is ideally complemented by a chief executive who can focus upon issues relating to the short-term implementation of operational issues.

The factor scores for each of the clusters is illustrated in Figure 1.

In the South African study, the four archetype preferred profiles of Chairmen identified were

\section{The statesman ( $38 \%$ of respondents)}

The statesman appears as a father-figure and coach who complements the chief executive by affording advice rather than being directly involved in operational decisions. As a coach. he'she is a detached outsider who relies heavily on expert opinion and works towards board commitment. yet is tolerant of dissent.

\section{The entrepreneur ( $29 \%$ of respondents)}

The entrepreneur is authoritarian. intuitive. tough. charismatic and strongly advances his her own point of view. He she is passionate about and deeply insolved in the operational issues of the business. evidencing less emphasis on broader socio-political issues. This chairman is skilful at playing multiple roles as determined by the situation. is flexible and is prepared to cut corners to reach decisions even if this involves breaking the rules. 

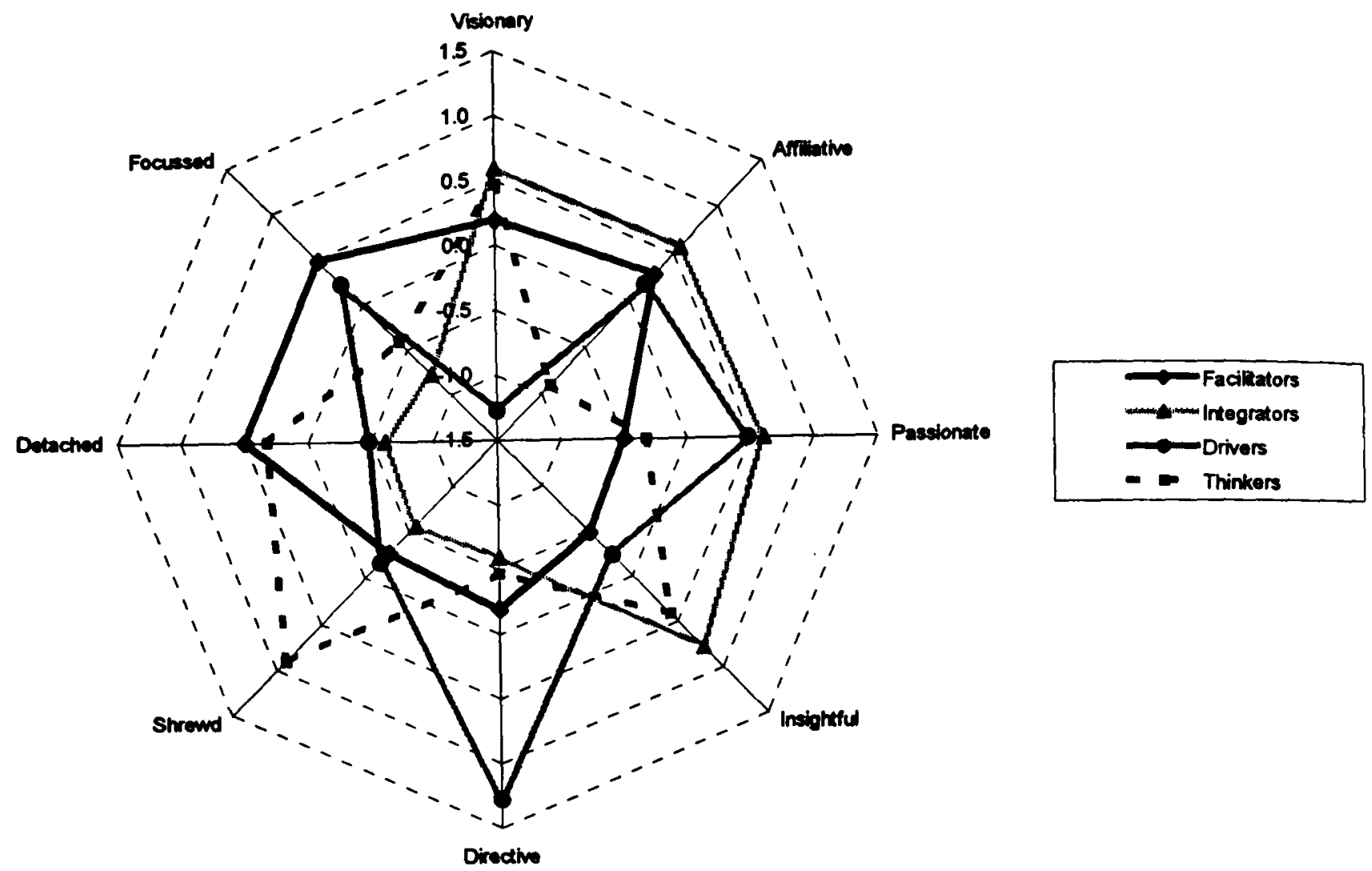

Figure 1 Bipolar factor scores by cluster - UK

\section{The driver ( $18 \%$ of respondents)}

The driver is personable, affable and, through good interpersonal skills, ensures the inclusion of all board members This chairman creates a long-term vision and, through trust, inspires commitment to and confidence in the vision. He/she evidences a tendency to become involved in operational issues but exercises constraint in doing so, thereby complementing the role of the chief executive.

The pioneer ( $15 \%$ of respondents)

The pioneer is reserved and incisive who gets to the heart of issues and effectively deals with them, usually with strong

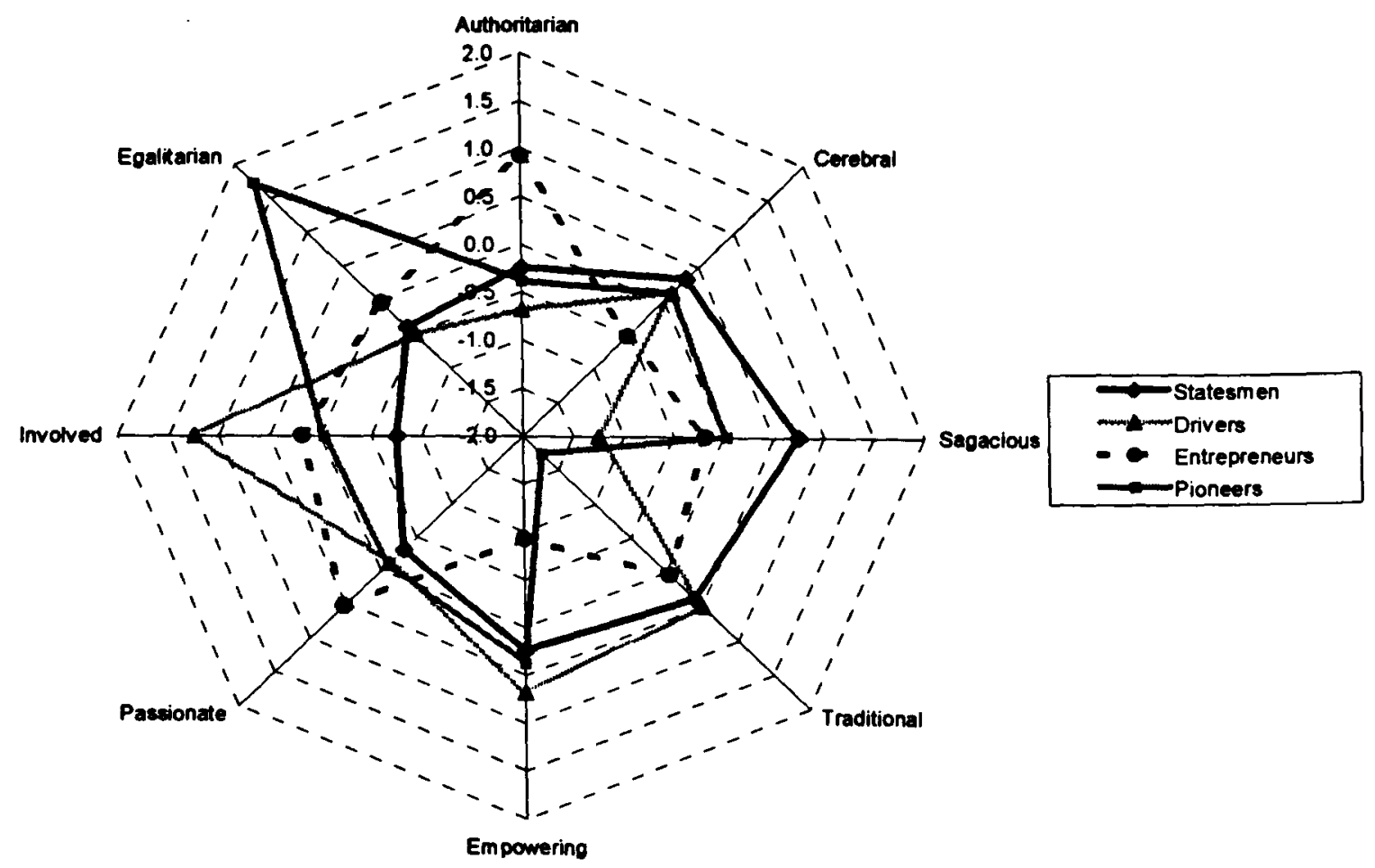

Figure 2 Biploar fact $r$ scores by cluster - South Africa 
adherence to rules. This chairman prefers to engage with groups rather than individuals, ensures the equitable treatment of all and is highly customer-oriented. He/she places emphasis on the broader socio-political issues, takes Africa (rather than Europe or the USA) as an anchor and believes that people should contribute to the business from the basis of their own cultures and perspectives. He/she views the roles of chairman/chief executive as separate yet overlapping and takes care not to compete with the chief executive.

The factor scores for each of the clusters is illustrated in Figure 2 .

\section{Contrasting the clusters}

The preferred profiles and their relationships are summarised in Tables 4 and 5.

From Tables 4 and 5, it appears that, while there are some similarities in the archetypes of 'good' chairmen in the UK and in South Africa, the dissimilarities, in terms of the combination of the factors, is more evident.

\section{Discussion}

Evaluation of UK and South African chairmen against the Cadbury and King recommendations

While there have been many studies and reports that identify the roles that chairmen should perform for the sake of good governance, the present study is focused upon perceptions of what qualities a 'good' chairmen should possess.

In the UK, the facilitator is rated as the most favoured type of chairman. In the UK, the globalisation of business, with its emphasis on technology, requires a visionary, rather than directive leadership style that is 'inspirational, empowering and big-picture, rather than decision oriented, pragmatic and hier- archical' (Knight \& Bell, 1997: 20). In this respect, the facilitator, as the most preferred archetype, also displays the most appropriate qualities for current and future corporate governance in the UK.

While the thinker, the next most favoured type of chairman, adequately enacts the role of separating the duties of the chairman and the chief executive as recommended by the Cadbury Report, he/she wields considerable power subtly in the background. This quality is questionable in terms of the requirements of good governance.

The authoritative and hands-on approach of the driver, the third most favoured chairman, 'is proprietorial and unquestionably the Boss' (Knight \& Bell, 1997: 13). As de facto chief executive, the qualities of this chairman archetype fly in the face of the recommendations of the Cadbury Report.

The integrator, the least preferred chairman, is both visionary and passionate. He/she is 'very hands on strategically and hands off operationally', with a style that 'is open, trusting, emphatic and empowering' (Knight \& Bell, 1977: 14). These qualities fully support the enactment of the roles recommended by the Cadbury Report but the strategic involvement of this chairman archetype could interfere with the separation of the duties of chairman and chief executive.

In sharp contrast to the UK environment, South A frican chairmen need to be cognisant of the transformation required to implement the inclusiveness required by the new labour legislation (Republic of South Africa, 1997; 1998).

In South Africa, the statesman is rated as the most favoured type of chairman. While the statesman does not interfere in day-to-day operational issues and works towards board commitment, this chairman does not evidence the integrative qualities required to ensure that all board members

Table 4 Preferred UK profiles and their relationships

\begin{tabular}{|c|c|c|c|c|}
\hline Preferred profile & $\begin{array}{c}\text { The facilitator } \\
(32 \%)\end{array}$ & $\begin{array}{l}\text { The thinker } \\
(25 \%)\end{array}$ & $\begin{array}{l}\text { The driver } \\
(23 \%)\end{array}$ & $\begin{array}{l}\text { The integrator } \\
(20 \%)\end{array}$ \\
\hline \multirow{4}{*}{$\begin{array}{l}\text { Poles of four axes in order of } \\
\text { strength }\end{array}$} & Detached & Shrewd & Directive & Insightful \\
\hline & Affiliative & Visionary & Passionate & Visionary \\
\hline & Visionary & Insightful & Focussed & Passionate \\
\hline & Focussed & Detached & Affiliative & Affiliative \\
\hline Leadership positioning & $\begin{array}{l}\text { Chief executive in } \\
\text { limelight; chairman } \\
\text { largely invisible }\end{array}$ & $\begin{array}{l}\text { Chief executive } \\
\text { leading, Chairman } \\
\text { in the shadows closely } \\
\text { watching or pulling the }\end{array}$ & $\begin{array}{l}\text { Chairman in full leadership } \\
\text { position; Chief } \\
\text { executive (if there is one) } \\
\text { sa number two }\end{array}$ & $\begin{array}{l}\text { Chairman and } \\
\text { chief executive } \\
\text { a double act }\end{array}$ \\
\hline $\begin{array}{l}\text { Chairman and chief executive } \\
\text { relationship }\end{array}$ & $\begin{array}{l}\text { warm. open } \\
\text { trusting, supportive } \\
\text { Chairman a father } \\
\text { figure; } \\
\text { shared values }\end{array}$ & $\begin{array}{l}\text { Slightly formal, } \\
\text { professional: } \\
\text { mutual respect; } \\
\text { watchful, likely to be co } \\
\text { mentary; }\end{array}$ & $\begin{array}{l}\text { Charismatic; } \\
\text { hierarchical; } \\
\text { leader-follower; } \\
\text { - replication of } \\
\text { style and values }\end{array}$ & $\begin{array}{l}\text { Partners; close } \\
\text { informal } \\
\text { strongly } \\
\text { complememtary;able to } \\
\text { work together through issues } \\
\end{array}$ \\
\hline Board style & $\begin{array}{l}\text { Inclusive, good } \\
\text { atmosphere. } \\
\text { participative, adding } \\
\text { value: supportive to } \\
\text { executives }\end{array}$ & $\begin{array}{l}\text { Process-driven: } \\
\text { challenging. } \\
\text { maybe contrived, } \\
\text { not always } \\
\text { comfortable }\end{array}$ & $\begin{array}{l}\text { Dominated by } \\
\text { chairman's } \\
\text { personality and } \\
\text { style }\end{array}$ & $\begin{array}{l}\text { Chairman and } \\
\text { chief executive } \\
\text { combining to } \\
\text { draw om and } \\
\text { draw in others as appropriate }\end{array}$ \\
\hline
\end{tabular}

Source: Knight \& Bell (1997: 18) 
Bendixen, M. \& Burger, B. 1998 . Cross-cultural management philosophy, Journal of Business Research, 42(2): 107-114.

Bendixen. M. \& Sandler, M. 1995. Converting verbal scales to interval scales using correspondence analysis, Management Dynamics, 4(1): 32-50.

Blair, M.M. 1995. Rethinking assumptions behind corporate govemance, Challenge, November-December: 12-17.

Boyd, B.K. 1995. CEO duality and firm performance: a contingency model, Strategic Management Journal, 16: 301-312.

Byme, D. Clore. G.L. \& Worchel, P. 1966. The effects of economic similarity-dissimilarity as determinants of attraction, Journal of Personality and Social Psychology, 4: 220-224.

Cadbury Report. 1992. The financial aspects of corporate governance. London: Gee.

Charkham. J. 1994. Keeping good company: a study of corporate governance in five countries. Oxford: Oxford University Press.

Clarke, T. 1998. The contribution of non-executive directors to the effectiveness of corporate governance, Career Development International, 3(3): 118-124

Commonwealth Association for Corporate Governance (CACG). 1999. CACG guidelines: principles for corporate governance in the commonwealth. Marlborough, New Zealand: CACG.

Conger, J.A., Finegold, D. \& Lawler, E.E. 1998. Appraising boardroom performance, Harvard Business Review, January-February: 136-148.

Conyon, M.J. 1994. Corporate governance changes in UK companies between 1988 and 1993, Corporate Governance 2(2): $97-$ 109.

Conyon, M.J. \& Mallin, C.A. 1997. A review of compliance with Cadbury, Journal of General Management, 22(3): 24-37.

Coulson-Thomas, C. 1993. Creating excellence in the boardroom. London: McGraw-Hill.

Coulson-Thomas, C. 1994. Developing directors: building an effective boardroom, Journal of European Industrial Training, 18(6): 29-52.

Daily, C.M. \& Dalton, D.R. 1995. CEO and director tumover in failing firms: an illusion of change?, Strategic Management Journal, 16: $393-400$

Dalton, D.R. \& Kesner, I.F. 1987. Composition and CEO duality in boards of directors: an international perspective, Journal of Inter national Business Studies, 18(3): 33-42.

Demb, A. \& Neubauer, F. 1992. The corporate board. New York: Oxford University Press.

Dobrzynski, J. 1991. Chairman and CEO: one hat too many, Business Week, 18 November: 124.

Dulewicz, V., MacMillan, K. \& Herbert, P. 1995. The development of standards of good practice for boards of directors, Executive Development, 8(6).

Fidler, J. 1981. The British business elite: its attitudes to class, status and power. London: Routledge and Kegan Paul.

Financial Mail, 1999. Blight on the pale males, Supplement, $27 \mathrm{Au}-$ gust: 24-29.

Finkelstein, S. 1992. Power in top management teams: dimensions, measurement, and validation, Academy of Management Journal, 35: 505-538.

Fransella, F. \& Bannister, D. 1977. A manual for repertory grid technique. London: Academic Press.

Garratt, R. 1996. The fish rots from the head. London: Harper Collins Business.

Garratt, R. 1998. Corporate governance, Boardroom, 3: 10-12.

Greenbury Report. 1995. London: Gee.

Glick, W.H., Miller, C.C. \& Huber, G.P. 1993. The impact of upper echelon diversity on organizational performance. In Huber, G.P. \& Glick, W.H. eds. Organizational change and redesign: ideas and insights for improving performance. New York: Oxford University Press: 176-124.
Hampel Report. 1998. Final report by the committee on corporate governance. London: Gee

Herman, E.S. 1981. Corporate control, corporate power. Cambridge: Cambridge University Press.

Institute of Directors. 1995. Standards for the board. London: IOD.

Jackson, N. \& Carter, P. 1995. Organizational chiaroscuro: throwing light on the concept of corporate governance. Human Relations, 48(8): 875-889.

Jackson, S.E., Stone, V.K. \& Alvarez, E.B. 1992. Socialization amidst diversity: the impact of demographics on work team oldtimers and newcomers. In Staw, B.M. \& Cummings, L.L. eds. Research in organizational behavior. 15. Greenwich, CT: JAI Press: 45-109.

Jarillo, J.C. 1998. On strategic networks, Strategic Management Journal, 9: 31-41.

Kelly, G.A. 1955. The psychology of personal constructs. Vols. 1 \& 2. New York: Norton.

King Report. 1994. The King Reporl on corporate governance. Johannesburg: Institute of Directors.

Knight, M. \& Bell, B. 1997. What does it take to be a good chairman? London: Corporate Consulting Group

Kosnik, R.D. 1987. Greenmail: a study of board performance in corporate governance, Administrative Science Quarterly, 32: 163185.

Leedy, P.D. 1997. Practical research: planning and design. 6th ed. New York: Macmillan.

Lorsch, J.W. 1989. Pawns or potentates: the reality of America's corporate boards. Boston: Harvard Business School Press.

Mallette, P. \& Fowler, K.L. 1992. Effects of board composition and stock ownership on the adoption of 'poison pills'. Academy of Management Journal, 35: 1010-1035

Matter, E. \& Ball. M. 1985. Handbook for corporate directors. New York: McGraw Hill \& Ball.

Michel, J.G. \& Hambrick, D.C. 1992. Diversification posture and top management team characteristics, Academy of Management Journal. 35: 9-37.

Miles, R.E. \& Snow, C.C. 1986. Organizations: new concepts for new forms, California Management Review, 28(3): 62-73.

Mintzberg, H. 1984. Who should control the corporation?. California Management Review, Fall: 90-115

Morck, R., Shleifer, A.\& Vishny, R.W. 1989. Alternative mechanisms for corporate control, American Economic Review, 79: 842852.

Patton, A. \& Baker, J.C. 1978. Why won't directors rock the boat? Harvard Business Review, 65(6): 10-18.

Pettigrew, A.M. \& McNulty, T. 1995. Power and influence in and around the boardroom, Human Relations, 48(8): 845-873.

Rechner, P.L. \& Dalton, D.R. 1991. CEO duality and organizational performance: a longitudinal analysis, Strategic Management Journal, 12: 155-160.

Republic of South Africa, 1997. Basic Conditions of Employment $A c t$, No. 75. Pretoria: Government Printer.

Republic of South Africa, 1998. Employment Equity Act. No. 55. Pretoria: Government Printer.

Ronan, N. 1996. Corporate governance in South Africa. Certified Accountant, 88(11): 44-45

Rossouw, G.J. 1997. Business ethics in South Africa. Journal of Business Ethics, 16(14): 1539-1547.

Shleifer. A. \& Vishny, R.W. 1997. A survey of corporate governance, Journal of Finance, 52(2): 737-782.

Southey, C. 1999. SA's big three hold all the levers, Financial Mail. 9 July: 32. 
Stangor, C., Lynch, L., Duan, C. \& Glass, B. 1992. Categorization of individuals on the basis of multiple social features, Journal of Personality and Social Psychology, 62: 207-218.

Starkey, K. 1995. Opening up corporate governance, Human Relations, 48(8): 837-884.

Stewart, R. 1991. Chairmen and chief executives: an exploration of their relationship, Journal of Management Studies, 28(5): 15111527.

Tajfel, H. \& Turner, J.C. 1986. The social identity theory in intergroup behavior. In Worchel, S. \& Autsin, W.G. eds. Psychology of intergroup relations. Chicago: Nelson-Hall: 7-24.

Thomas, A. \& Robertshaw, D. 1999. Achieving employment equity: a guide to effective strategies. Randburg: Knowledge Resources.

Thomas, A. \& Schonken, J.S. 1998. Culture specific management and the African management movement: verifying the premises, South African Journal of Business Management, 29(2): 67-75.

Tsui, A.S., Egan, T.D. \& O'Reilly, C.A. 1975. Being different: relational demography and organizational attachment, Administrative Science Quarterly, 37: 549-579.

Useem, M. 1993. Executive defence: shareholder power and corpo- rate reorganization. Cambridge, MA: Harvard University Press.

Vinten, G. 1998. Corporate governance: an international state of the art, Managerial Auditing Journal, 13(7); 419-431.

Walso, C.N. 1985. Boards of directors: their changing roles, structure, and information needs. Westport, CT: Quorum Books.

Weidenbaum, M.L. 1986. Updating the corporate board, Journal of Business Strategy, 7: 77-83.

Westphal, J.D. \& Zajac, E.J. 1995. Who shall govern? CEO/board power, demographic similarity, and new director selection, Administrative Science Quarterly, 40: 60-83.

Wexley, K.N. \& Nemeroff, W.F. 1974. The effects of racial prejudice, race of applicant and biographical similarity on interviewer evaluations of job applicants, Journal of Social and Behavioral Science, 20: 66-78.

Wiersema, M.F. \& Bantel, K.A. 1992. Top management team demography and corporate strategic change, Academy of Management Journal, 35: 91-121

Woodburn, T., Mclldowie, P., Thomas, A., Bendixen, M. \& Wilkinson, R. 1999. What makes a good chairman in South Africa? Johannesburg: Woodburn Mann, IOD \& WBS. 